\title{
Desain Pendidikan Akhlak di Sekolah Menengah Pertama 2 Jember
}

\author{
Ahmad Royani \\ Institut Agama Islam Negeri Jember \\ royanpuritanjung@gmail.com
}

\begin{abstract}
The emergence of the counter-productive in the world of education has led to the emergence of symptoms among the youths, even the adults, which show that they ignore the moral values and manners needed in a civilized society. Concerns about moral decadence, it is like a double-edged knife. If you are looking for the root of the problem on others, it is essentially be the root of the problem of yourself; so, blaming others means also blaming themselves. Thus, it is necessary to find the solution and the moral education in an appropriate action. This research on "Model of Moral Education in SMP 2 Jember" is done based on these concerns. The results of this study address that the design of applicative-integrative moral education in SMPN 2 Jember is applied into four models; first, it is integrated with the teaching and learning activities; second, it is included in the school culture that covering the school routine activities which are already programmed, and also the spontaneous activity, the exemplary of the educators and education personnel, and the physical and non-physical conditioning; third, the extra-curricular activities as the additional activity in SMPN 2 Jember; and fourth, comunity-based activities that involve the parents and societies in the implementation of applicative-integrative moral education.
\end{abstract}

Key word: Educaion, Akhlak, Scholl

Abstrak : Munculnya counter productive dalam dunia pendidikan telah menyebabkan munculnya gejalagejala di kalangan anak muda, babkan orang tua, yang menunjukekan babwa mereka mengabaikan nilai dan moral dalam tata krama pergaulan yang sangat diperlukan dalam suatu masyarakat yang beradab. Keprihatinan terhadap dekadensi moral ibarat sebilah pisau bermata dua. Jika mencari akar masalah pada orang lain pada hakikatnya akar masalab itu juga bermula dari diri sendiri sebingga menyalabkan orang lain berarti pula menyalabkan diri sendiri. Untuk itu perlu dicarikan solusi dan aksi pendidikan akblak yang tepat. Penelitian mengenai "Model Pendidikan Akblak. Aplikatif-Integratif di SMPN 2 Jember" dilakukan berpijak dari keprihatinan tersebut. Hasil penelitian ini menujukan bahwa desain pendidikan akblak aplikatif integratif di SMP Negeri 2 Jember dengan menerapkan empat model, pertama terintegrasi dengan kegiatan belajar mengajar (KBM). Kedua buadaya sekolah yang meliputi kegiatan rutin yang merupakan kegiatan sudah terprogam, kegiatan spontan, keteladanan dari tenaga pendidik dan tenaga kependidikan, pengkondisian fisik maupun non-fisik. Ketiga kegiatan ekstra kurikuler yang merupakan kegiatan tambahan di SMPN 2 Jember. Keempat Kegiatan berbasis komonitas yang melibatkean orang tua dan masyarakat dalam pelaksanaan pendidikan akblak aplikatif integratif.

Kata Kuci; Pendidikan, Akhlak, Sekolah

\section{Pendahuluan}

Globalisasi yang ada dihadapan kita sebagai sebuah fakta yang tidak bisa diingkari.revolusi teknologi, transformasi, informasi dan komonikasi menjadikan dunia ini tanpa batas. Globalisai tidak hanya membawa dampak postif, tapi juga negatif. Kompetisi, integrasi dan kerjasama adalah dampak postif dari globalisasi. Lahirnya generasi instan (generasi now, lansung bisa menikmati keinginan tanpa proses perjuangan dan kerja kera), dekadensi 
moral,konsumerisme bahkan permisifisme adalah sebagaian dampak negatif dari globalisai. ${ }^{1}$

Di sinilah, pentinya pendidikan akhlak, karakter dan juga moral yang digunakan sebagai filterisasi agar lahir kesadaran bersama untuk membangun karakter, akhlak dan moral generasi muda bangsa yang kokoh.sehingga mereka tidak terobang ambing oleh modernosasi yang menjanjikan kenikmatan sesaat serta mengorbankan kenikmatan masa depan yang panjang dan abadi.

Lembaga pendidikan hingga saat ini masih dipercayai sebagai salah satu media untuk bisa mencetak insan yang cerdasdan sekaligus menjadikan kepribadian anak menjadi lebih baik. Oleh karenaya pendidikan secara terus menerus dibangun dan dikembangkan agar dalam proses pelaksanaanya menghasilkan generasi yang diharapkan.

Tujuan utama pendidikan adalah untuk membentuk manusia yang good and smart. Atau dalam Islam mengupayakan agar manusia memiliki karakter yang baik (good character). Dengan bahasa sederhana adalah merubah manusia menjadi lebih baik dalam pengetahun, sikap dan keterampilan. Namun, pada prakteknya lebih ditekankan pada aspek prestasi akademik (academic achievement), sehingga mengabaikan pembentukan karakter siswa. Walaupun dalam teori sosiologi menyebutkann bahwa pembentukan karakter menjadi tugas utama keluarga, namun sekolah pun ikut bertanggung terhadap kegagalan pembentukan karakter di kalangan para siswanya, karena proses pembudayaan menjadi tanggungjawab sekolah. Pendidikan karakter bagi sekolah bukan lagi sebagai sebuah opsi, tetapi suatu keharusan yang tak terhindarkan. karena pendidikan di mana pun akan berkenaan dengan tugas olah pikir (pengetahuan), olah rasa (apresiasi), dan olah raga (keterampilan) dalam konteks kehidupan psikologis, sosial dan kultural. Dari konteks inilah nilai-nilai (value), lingkungan, dan spiritual akan menjadi bahan untuk membentuk karakter anak didik.

Sekolah Menengah Pertama Negeri (SMPN) 2 Jember di bawah Dinas Pendidikan Pemkab Jember. lembaga ini merupakan salah satu sekolah favorit di lingkungannya dan menjadikan "akhlak mulia" sebagai misi utama dalam mencetak lulusannya selain prestasi akademik yang unggul. Pilihan pada lembaga tersebut juga berdasarkan pengamatan awal yang dilakukan peneliti bahwa di dalamnya terindikasi telah berlangsung proses pendidikan akhlak hingga taraf pembiasaan berakhlak mulia dalam keseharian siswa dan pendidikan (aplikatif) akhlak ini tidak hanya berupa mata pelajajan P.A.I. yang terstruktur dalam kurikulum nasional (kurnas) tetapi menjadi bagian

1Jamal Ma'ruf Asmani, Buku Panduan Internalisasi Pendidikan karakter di Sekolah, (Yogyakarta; Diva Press, 2013) 
muatan kurikulum terpadu (integratif) bagi setiap mata pelajaran lain yang mesti dilakukan oleh semua Pendidik bidang studi.

Pendidikan akhlak yang berlangsung di SMP Negeri 2 Jember dengan penyampaian materi akhlak melalui pembelajaran bidang studi PAI, Pengembangan Karakter dan PPKn. Bagi Pendidik bidang studi lain juga diminta memperhatikan pembinaan akhlak siswa dengan memberikan catatan-catatan penyimpangan moral untuk disampaikan pada BK-Wali Kelas sebagai acuan penilaian raport aspek perilaku yang meliputi kelakuan, kerajinan, dan kerapian.

Secara umum bahasan mengenai implementasi pendidikan akhlak adalah berupa pengejawantahan kurikulum formal yang meliputi persiapan, proses pelaksanaan, strategi pendidikan, teknik evaluasi dan program pendidikan akhlak berkelanjutan secara terpadu (integratif) hingga terjadi pembiasaan dan pembentukan akhlak mulia secara aplikatif. Upaya pembentukan akhlak secara aplikatif yang dilakukan oleh semua Pendidik bahkan oleh semua civitas sekolah adalah menjadi bagian tanggung jawab bersama yang menuntut keterlibatan dan peran masing-masing. Maka penelitian tentang pendidikan akhlak yang memungkinkan seseorang dapat melakukannya tanpa terikat dengan aturan kurikulum formal. Penelitian ini menjadi menarik dan perlu dilakukan terutama sebagai upaya pencarian model pendidikan akhlak, setidaknya menjadi suatu gagasan mengenai pentingnya pendidikan akhlak yang dapat diterapkan di lembaga pendidikan manapun. Maka berangkat dari fenomena diatas peneliti mengambil judul “ Desain Pendidikan Akhlak di SMPN 2 Jember"

\section{Metodologi Penelitian}

Penelitian ini lebih bersifat lapangan (field research). Guna memperoleh hasil yang optimal, peneliti mengadakan interaksi dengan pihak lembaga pendidikan yang dijadikan tembat penelitian, para Pendidik dan siswa serta orang tua siswa, dengan harapan dapat memperoleh informasi yang kongkrit. Dengan demikian data dan konsep yang telah ada di lingkungan pendidikan dapat segera diketahui. Adapun metode penelitian yang digunakan adalah metode deskriptif - kualitatif dengan pendekatan fenomenologi. Timbulnya sikap komunikatif sangat membantu dalam mengumpulkan data sebagai instrumen. Dalam penelitian ini, peneliti merupakan instrumen utama dalam pengumpulan data, sehingga dengan kemampuannya menyesuaikan diri dengan berbagai ragam realitas yang tidak dapat dikerjakan oleh instrument non-buman, dapat menangkap makna dan memahami fenomena ${ }^{2}$ yang terjadi di SMPN 2 Jember.

${ }^{2}$ Noeng Muhadjir, Metodologi Penelitian Kualitatif (Yogyakarta: Rake Sarasin, 2004) 108- 
Penelitian ini dilakukan dalam situasi yang wajar atau dalam natural setting, tanpa dimanipulasi dan tanpa diatur dengan eksperimen atau tes. Dengan kata lain bahwa sumber data dan data dalam penelitian ini diambil dalam situasi yang alami dengan mempertimbangkan konteks di mana fenomena tersebut terjadi. Karena itu, penelitian ini menggunakan pendekatan fenomenologis. Dalam arti berusaha menemukan kembali pengalaman dasar (basic experience) berupa nilai-nilai dasar dari upaya internalisasi pendidikan akhlak bagi peserta didik secara integratif.

Penelitian ini tidak dimaksudkan untuk menghasilkan generalisasi, sebagaimana penelitian kuantitatif yang memberlakukan prinsip-prinsip hasil penelitian secara universal bagi semua kasus. ${ }^{3}$ Penelitian ini ditujukan untuk membentuk teori berdasarkan saling berhubungan antara data yang ditemukan dan berdasarkan temuan yang dihasilkan. Peneliti dapat menggunakannya sesuai dengan situasi dan kondisi.

\section{Kajian Tentang Pendidikan Akhlak Di Sekolah}

Seiring dengan derasnya informasi dan tranformasi Global yang masuk menyebabkan terjadinya berfikir dalam masyarakat, terutama kalangan anakanak yang berada dalam keadaan tumbuh dan berkembang sehingga para siswa sangat membutuhkan segala bentuk bimbingan dan nasehat agar tidak terjerumus dalam pergaulan yang salah. Tidak salah ketika presiden Jokowi pada 6 September 2017, menandatangani Peraturan Presiden (Perpres) Nomor: 87 Tahun 2017 tentang Penguatan Pendidikan Karakter. Penguatan Pendidikan Karakter yang selanjutnya disingkat PPK merupakan gerakan pendidikan di bawah tanggung jawab satuan pendidikan untuk memperkuat karakter peserta didik melalui harmonisasi olah hati, olah rasa, olah pikir, dan olah raga dengan pelibatan dan kerja sama antara satuan pendidikan, keluarga, dan masyarakat sebagai bagian dari gerakan nasional revolusi mental. Untuk memenuhi kepentingan penguatan karakter tersebut, maka dituntut adanya keterampilan para personil pendidikan agar dapat mengelola kegiatan pembelajaran secara lebih efektif dan efisien. Pola kerjasama yang membangun antara guru dan peserta didik sangat penting dilakukan. Model mendidik dengan cinta merupakan modal dasar penguatan karakter siswa untuk bisa mengembangkan potensi yang ada pada dirinya.

Pembelajaran Terpadu adalah pembelajaran yang menggunakan prinsip terpadu dengan menggunakan tema pemersatu dalam memadukan beberapa mata pelajaran sekaligus pada satu kali tatap muka sehingga memberikan pengalaman peserta yang bermakna. ${ }^{4}$ Membahas Pendidikan akhlak berarti

\footnotetext{
${ }^{3}$ S. Nasution, Metode Penelitian Naturalistik Kualitatif (Bandung: Trasinto, 1996), 15.

${ }^{4}$ Trianto, Model Pembelajaran Terpadu, Konsep Strategi dan Implementasinya Dalam KTSP, (Jakarta:PT Bumi Aksara, 2010) 8
} 
pula mengupas tentang upaya pembentukan akhlak mulia melalui seluruh proses pendidikan. Abuddin Nata menguraikan bahwa "akhlak merupakan hasil usaha dalam mendidik dan melatih dengan sungguh-sungguh terhadap segala potensi rohaniyah yang terdapat pada diri manusia. Jika program pendidikan dan pembinaan akhlak dirancang dengan baik, sistematik dan dilaksanakan sungguh-sungguh, akan menghasilkan anak-anak dan orangorang yang baik akhlaknya. Di sinilah letak peran dan fungsi lembaga pendidikan". ${ }^{5}$ Nata memandang usaha pendidikan akhlak ini sebagai upaya yang menyangkut pembentukan perilaku akhlak, sehingga segala bentuk pembelajaran akhlak harus berujung pada aplikasi (penerapan) perilakuperilaku baik (al-akblaq al-karimah). Ibn Miskawaih sejak awal menegaskan bahwa akhlak hanya dapat dibentuk melalui pendidikan dan pembiasaan. Ia menolak anggapan bahwa anak-anak akan berkembang sesuai perkembangannya tanpa pembiasaan dan pendidikan. ${ }^{6}$

Ki Hajar Dewantara menyebutkan, manusia memilki daya cipta, karsa dan karya. ${ }^{7}$ Pengembangan manusia seutuhnya menuntut pengembangan semua daya secara seimbang. Pengembangan yang terlalu menitik beratkan pada satu daya saja akan menghasilkan ketidakutuhan perkembangan sebagai manusia. Beliau mengatakan bahwa pendidikan yang menekankan pada aspek intelektual saja hanya akan mejauhkan peserta didik dari masyarakatnya. Ternyata pendidikan sampai sekarang ini hanya menekankan pada pengembangan daya cipta, dan kurang memperhatikan pengembangan olah rasa dan karsa. Jika ini berlanjut akan menjadikan manusia kurang humanis atau manusiawi.

Melakukan proses pendidikan akhlak tidak cukup melalui bidang studi akhlak semata tetapi mencakup bidang studi secara keseluruhan, bahkan mencakup seluruh program pendidikan secara integratif. Hasil rumusan Kemendiknas dan Kemenag menyimpulkan bahwa pendidikan budi pekerti (akhlak) bukan merupakan mata pelajaran tersendiri (monolitik), tetapi merupakan program pendidikan terpadu yang memerlukan prilaku, keteladanan, pembiasaan, bimbingan dan penciptaan lingkungan moralitas yang kondusif. ${ }^{8} \quad$ Pendidikan akhlak dapat menjadi soft skill (dampak pengiring) bagi setiap mata pelajaran. Hal ini bisa dilakukan, antara lain dengan memasukkan character-based approach sebagai upaya membangun karakter peserta didik yang berbudi luhur secara bersama-sama. Inilah bentuk upaya mengupayakan proses pendidikan akhlak secara integratif yang menjadi bagian penting dari pengembangan kurikulum 2004 yang bercorak

${ }^{5}$ Abuddin Nata, Akblak Tasamuf (Jakarta: RG Persada, 2006), 158.

'Ibnu Miskawaih, Tabdrib, 112.

${ }^{7}$ Soejono. Aliran Baru Dalam Pendidikan Islam. (bandung: CV ilmu. 1979). 93

${ }^{8}$ Azyumardi Azra, Paradigma .. , 187-188. 
KBK (Kurikulum Berbasis Kompetensi) menjadi KTSP (Kurikulum Tingkat Satuan Pendidikan) pada 2006 dan menjadi tugas penting bagi sekolah atau Sekolah untuk melakukan improvisasi guna meningkatkan mutu pendidikan, terutama dalam menanamkan dan membentuk kebiasaan berakhlak mulia bagi peserta didik. Pada tahun 2013 disempurnakan dengan kurikulum yang mengintegrasikan pendidikan karakter dalam setiap mata pelajaran.

Pendidikan akhlak tidak cukup hanya dengan meletakkan dasar kebaikan perilaku dalam seluruh bidang studi dan menjadikannya sebagai satu kesatuan sistematis dalam membangun karakter peserta didik. Tidak cukup pula menciptakan lingkungan yang dapat menumbuhkan budi pekerti luhur hanya di sekolah, tetapi juga harus menciptakan lingkungan akhlak mulia ini terutama di lingkungan keluarga dan masyarakat, sehingga pendidikan akhlak integratif yang melibatkan semua pihak menjadi tanggung jawab bersama antara sekolah, keluarga dan masyarakat.' Berikut skema pembelajaran pendidikan akhlak aplikatif intergratif.

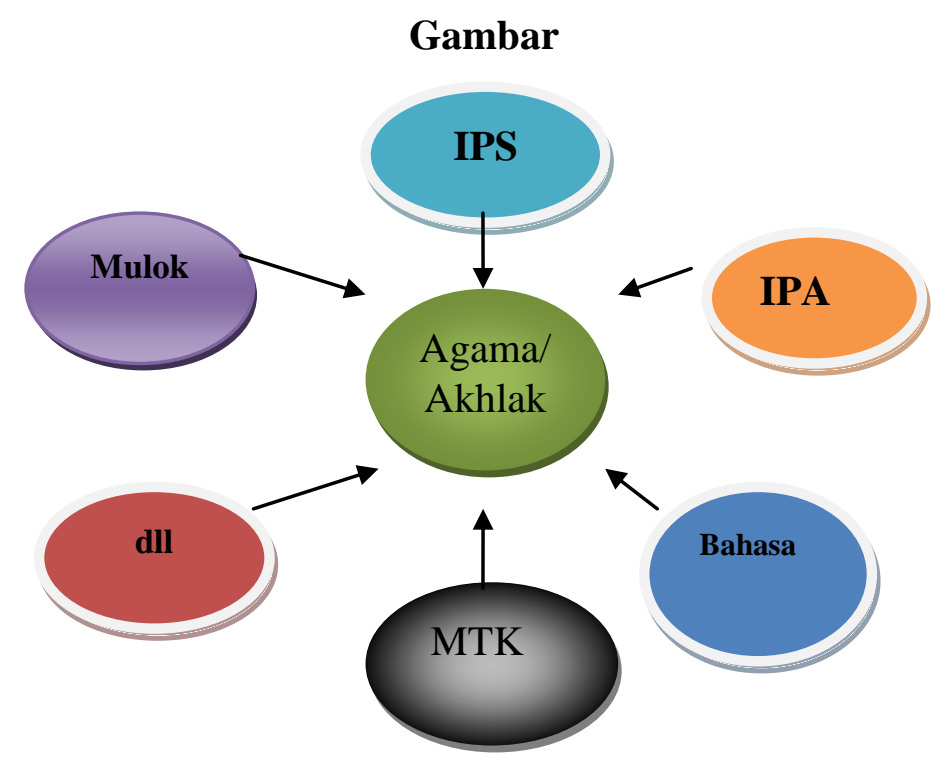

Dalam skema diatas merupakan model pendidikan ahlak yang terintegrasi kedalam setiap mata pelajaran. Dimana dalam hal ini Pendidik di anjurkan untuk menanamkan nilai pendidikan akhlak/ moral kepada siswa.

Amirulloh Syarbini dalam bukunya yang berjudul "pendidikan karakter: panduan lengkap mendidik karakter anak di sekolah, Sekolah dan rumah"

'Jamal Ma'ruf Asamani, Buku Panduan Pendidikan Karakter di Sekolah. (Yogyakarta: Diva Press: 2013) 155 
membagi desain pendidikan akhlak/ pengembangan karakter disekolah menjadi empat desain diantaranya yaitu: ${ }^{10}$

Pertama, mengintegrasikan ke setiap mata pelajaran. Mengintegrasikan ke setiap mata pelajaran tujuan untuk memperkenalkan nilai-nilai akhlak disetiap mata pelajaran, sehingga menyadari akan pentingnya nilai tersebut. Nilai-nilai tersebut dicantumkan dalam silabus dan RPP. Pengembangan nilai-nilai itu dalam silabus ditempuh melalui cara-cara berikut ini: 1) mengkaji Standar Komptensi (SK) dan Kompetensi Dasar (KD) pada Standar Isi (SI) untuk menentukan apakah nilai-nilai budaya dan karakter bangsa yang tercantum itu sudah tercakup di dalamnya.. 2) menggunakan yang memperlihatkan keterkaitan antara SK dan KD dengan nilai dan indikator untuk menentukan nilai yang akan dikembangkan, 3) mencantumkankan nilai-nilai budaya dan karakter bangsa dalam tabel 1 itu ke dalam silabus; 4) mencantumkan nilai-nilai yang sudah tertera dalam silabus ke dalam RPP , 5) mengembangkan proses pembelajaran peserta didik secara aktif yang memungkinkan peserta didik memiliki kesempatan melakukan internalisasi nilai dan menunjukkannya dalam perilaku yang sesuai; dan memberikan bantuan kepada peserta didik, baik yang mengalami kesulitan untuk menginternalisasi nilai maupun untuk menunjukkannya dalam perilaku

Kedua, Pengembangan budaya sekolah maksudnya yang membentuk akhlak siswa adalah pranata sosial sekolah kerena merekalah yang lebih tau nilai-nilai apa yang harus dimiliki oleh pesrta didik agar menjadi manusia yang berakhlak. Budaya sekolah cakupannya sangat luas, umumnya mencakup ritual, harapan, hubungan, demografi, kegiatan kurikuler, kegiatan ekstrakurikuler, proses mengambil keputusan, kebijakan maupun interaksi sosial antarkomponen di sekolah. Budaya sekolah adalah suasana kehidupan sekolah tempat peserta didik berinteraksi dengan sesamanya, Pendidik dengan Pendidik, konselor dengan sesamanya, pegawai administrasi dengan sesamanya, dan antaranggota kelompok masyarakat sekolah. Interaksi internal kelompok dan antarkelompok terikat oleh berbagai aturan, norma, moral serta etika bersama yang berlaku di suatu sekolah. Kepemimpinan, keteladanan, keramahan, toleransi, kerja keras, disiplin, kepedulian sosial, kepedulian lingkungan, rasa kebangsaan, dan tanggung jawab merupakan nilai-nilai yang dikembangkan dalam budaya sekolah. Pengembangan nilainilai dalam pendidikan budaya dan karakter bangsa dalam budaya sekolah mencakup kegiatan-kegiatan yang dilakukan kepala sekolah, Pendidik, konselor, tenaga administrasi ketika berkomunikasi dengan peserta didik dan menggunakan fasilitas sekolah

${ }^{10}$ Amirullah Syarbini, Bukun Pintar Pendidikan Karkter " Panduan Lengkap Mendidik Karakter Anak di sekolah, Sekolah dan Rumah, (Jakarta: As@- Prima pusataka) 59-61 
Ketiga, melalui kegiatan ekstrakurikuler, kegiatan ekstrakurikuler merupakan kegiatan sekolah yang ada diluar mata pelajaran yang bertujuan untuk membentuk kreatuvitas siswa untuk bisa menyalurkan bakat, minat dalam rangka mendukung kemandirian siswa.

Keempat, desain berbasis komonitas dimana sekolah melibatkan orang tua dan masayarakat dalam membentuk akhlak peserta didik. Ki Hajar Dewantara menyebutkan pola kerjasama antara keluarga, masyarakat, dan sekolah (tripusat pendidikan) dalam membentuk budipekerti sangat dibutuhkan oleh karena itu peran ketiganya tidak bisa dipisahkan. ${ }^{11}$ Pendidikan memiliki peranan yang sangat besar dalam membentuk kepribadian setiap manusia. Pendidikan merupakan proses pengembangan potensi peserta didik sehingga menjadi pribadi yang paripurna (insan kami ). Salah satu indikator insan kamil tersebut adalah setiap peserta didik melahirkan akblaq al-karimah. Sebagaimana yang dikemukakan oleh Ki Hajar Dewantara ${ }^{12}$, bahwa ada tiga lembaga pendidikan yang turut berperan dalam mengembangkan potensi tersebut, yaitu pendidikan formal, informal dan non formal. Pendidikan formal diwakili oleh sekolah, pendidikan informal diwakili oleh keluarga dan pendidikan non formal dilakukan oleh masyarakat. Dengan demikian sekolah sebagai lembaga pendidikan formal turut bertanggung jawab dalam mendidik akhlak setiap peserta didiknya. Itu sebabnya, ketika muncul perilaku negatif (akblaq madhmumah) di tengah-tengah masyarakat, maka salah satu faktor yang disorot adalah bidang pendidikan, di samping faktor-faktor lainnya.

Dengan demikian berdasarkan paparan di atas, dapat disimpulkan bahwa dalam konteks sistem pendidikan di sekolah untuk mengembangkan pendidikan akhlak peserta didik, Pendidik harus diposisikan atau memposisikan diri pada hakekat yang sebenarnya, yaitu $:^{13}$ a) Pendidik merupakan pengajar dan pendidik, yang berarti disamping mentransfer ilmu pengetahuan, juga mendidik dan mengembangkan kepribadian peserta didik melalui intraksi yang dilakukannya di kelas dan luuar kelas; b) Pendidik hendaknya diberikan hak penuh (hak mutlak) dalam melakukan penilaian (evaluasi) proses pembelajaran, karena dalam masalah kepribadian atau karakter peserta didik, Pendidik merupakan pihak yang paling mengetahui tentang kondisi dan perkembangannya; dan c) Pendidik hendaknya mengembangkan sistem evaluasi yang lebih menitikberatkan pada aspek afektif, dengan menggunkan alat dan bentuk penilaian essay dan wawancara

\footnotetext{
${ }^{11}$ Budi raharjo, Biografi Singkat Kihajar Deawntara, (Yogyakarta: Arruz Media, 2011) 42

${ }^{12}$ Lebih lengkap lihat Majelis Luhur Persatuan Taman Siswa, Karya Ki hajar Dewantara Bagian I Pendidikan (Yogyakarta: MLTM, 1977)

${ }^{13}$ Imam Machalli, Pendidikan Karakter " Pengalaman Implementasi pendidikan Karakter di Sekolab" 56
} 
langsung dengan peserta didik. Alat dan bentuk penilaian seperti itu, lebih dapat mengukur karakteristif setiap peserta didik, serta mampu mengukur sikap kejujuran, kemandirian, kemampuan berkomunikasi, struktur logika, dan lain sebagainya yang merupakan bagian dari proses pembentukan karakter positif. Ini akan terlaksana dengan lebih baik lagi apabila didukung oleh pemerintah selaku penentu kebijakan

\section{Desain Pendidikan Akhlak Di Sekolah Menegah Pertama Negeri 2 Jember}

Desain yang dilakukan oleh SMPN 2 Jember dalam melaksanakan pendidikan akhlak aplikatif integratif sekolah mendesain dengan empat desain, pertama integrasi dengan mata pelajaran, kedua terintegrasi dengan budaya sekolah, ketiga terintegrasi melalui kegiatan ekstrakulikuler dan keempat terintegrasi dalam kegiatan masyarakat dan keluarga dengan kerjasama orang tua wali murid.

\section{Integrasi dengan mata Pelajaran; Upaya mempekuat pemahaman}

Pengertian kurikulum sebagai pengalaman belajar mengandung makna bahwa kurikulum adalah seluruh kegiatan yang dilakukan siswa baik di dalam maupun di luar sekolah asal kegiatan tersebut berada di bawah tanggung jawab guru ( sekolah). Yang dimaksud dengan kegiatan itu tidak terbatas pada kegiatan intra maupun ekstra kurikuler. Apa pun yang dilakukan siswa asal saja ada di bawah tanggung jawab dan bimbingan guru, itu adalah kurikulum. ${ }^{14}$

Secara normatif, integrated curriculum (Kurikulum Terpadu) dapat diartikan sebagai suatu produk dari usaha pengintegrasian bahan ajar dari berbagai pelajaran. Integrasi diciptakan dengan memusatkan pelajaran pada masalah tertentu yang memerlukan solusinya dengan materi atau bahan dari berbagai disiplin ilmu atau mata pelajaran. ${ }^{15}$

Pelaksanaan pendidikan akhlak di SMP Negeri 2 Jember dalam rangka penanaman pendidikan budaya akhlak desain yang digunakan salahsatunya adalah penerapan dalam mata pelejaran dan juga melalui pendekatan budaya. Pelaksanaan pendidikan akhlak di SMPN 2 Jember dengan menggunakan dua pendekatan. Pertama, integrated curriculum dimana pendidikan akhlak terintegrasi kedalam semua mata pelajaran. Kedua, melaui bidden curriculum, yang terintegrasi kedalam budaya sekolah.

Pelaksanaan proses belajar mengajar esensisinya adalah menanamkan kepada siswa agar bisa lebih mandiri. Kegiatan kognitif afektif dan pskomotrik siswa merupakan satu kepaduan yang tidak bisa

\footnotetext{
${ }^{14}$ Oemar Hamalik, Kurikulum dan Pembelajaran (Jakarta: Bumi Aksara, Jakarta, 1999), 33.

${ }^{15}$ Abdullah Idi, Pengembangan Kurikulum Teori dan Praktek (Jogjakarta: Ar-Ruzz Media, 2007), 146.
} 
dipisahkan antara satu dengan lainya. SMPN 2 Jember dalam proses penanaman pendidikan akhlak salahsatunya dengan menggunakan metode integrasi kedalam semua mata pelajaran. Pengembangan nilai-nilai dan budaya akhlak diintegrasikan dalam setiap pokok bahasan dari setiap mata pelajaran. Nilai-nilai tersebut dicantumkan dalam Silabus dan Rencana Pelaksanaan Pembelajaran (RPP). Pengembangan nilai-nilai tersebut dalam Silabus ditempuh melalui. 1) Mengkaji Standar Kompetensi (SK) dan Kompetensi Dasar (KD) untuk menentukan apakah kandungan nilai-nilai dan karakter yang secara tersirat atau tersurat dalam SK dan KD di atas sudah tercakup di dalamnya. 2) Menggunakan tabel rumusan SKL dengan karakter yang memperlihatkan keterkaitan antara SK/KD dengan nilai dan indikator untuk menentukan nilai yang akan dikembangkan. 3) Mencantumkan nilai-nilai dan karakter bangsa ke dalam silabus. 4) Mencantumkan nilai-nilai yang sudah tercantum dalam silabus ke RPP. 5) Mengembangkan proses pembelajaran peserta didik aktif yang memungkinkan peserta didik memiliki kesempatan melakukan internalisasi nilai dan menunjukkannya dalam perilaku yang sesuai. 6) Memberikan bantuan kepada peserta didik yang mengalami kesulitan untuk internalisasi nilai maupun untuk menunjukkannya dalam perilaku.

\section{Integrasi dengan Budaya Sekolah; Upaya menanamkan kebiasaan}

Selain proses belajar mengajar di kelas kegiatan yang dilakukan di SMPN 2 Jember adalah bidden curriculum. Proses ini adalah kegiatan budaya berbasis nilai yang menjadi kebiasaan sekolah dalam lingkungan sekolah. Kurikulum yang tersembunyi ini sangat memengaruhi proses pembelajaran yang dialami siswa. Dalam proses pendidikan dipengaruhi oleh faktor majemuk. Faktor yang satu saling berpengaruh terhadap faktor yang lainnya. Namun demikian, faktor yang paling penting adalah Pendidik, karena hitam-putihnya proses belajar mengajar di dalam kelas banyak dipengaruhi oleh mutu Pendidiknya. Pendidik dikenal sebagai bidden curriculum (kurikulum tersembunyi), karena sikap dan tingkah laku, penampilan profesional, kemampuan individual dan apa saja yang melekat pada pribadi sang Pendidik, akan diterima oleh peserta didiknya sebagai rambu-rambu untuk diteladani atau dijadikan bahan pembelajaran.

Berdasarkan wawancara dengan kepala sekolah SMPN 2 Jember kegiatan akhlak berbasis nilai merupakan aktifitas Interaksi internal kelompok dan antarkelompok terikat oleh berbagai aturan, norma, moral serta etika bersama yang berlaku di suatu sekolah. Kepemimpinan, keteladanan, keramahan, toleransi, kerja keras, disiplin, kepedulian sosial, kepedulian lingkungan, dan tanggung jawab merupakan nilai-nilai yang 
dikembangkan dalam kurikulum tersembunyi.Pengembangan nilai-nilai dalam pendidikan budaya akhlak mencakup kegiatan-kegiatan yang dilakukan kepala sekolah, guru, konselor, tenaga administrasi ketika berkomunikasi dengan peserta didik dan menggunakan fasilitas sekolah.

\section{Integrasi Melalui Kegiatan Ekstrakulikuler; Perkuat Kemandirian} Siswa

Melalui kegiatan ekstrakurikuler, kegiatan ekstrakurikuler merupakan kegiatan sekolah yang ada diluar mata pelajaran yang bertujuan untuk membentuk kreatuvitas siswa untuk bisa menyalurkan bakat, minat dalam rangka mendukung kemandirian siswa. Kegiatan ekstrakulikuler ditujukan agar siswa dapat mengembangkan kepribadian, bakat dan kemampuannya diberbagai bidang diluar bidang akademik. Kegiatan dari ekstrakulikuler ini sendiri dapat berbentuk kegiatan pada seni, olahraga, pengembangan kepribadian, dan kegiatan lain yang bertujuan positif untuk kemajuan siswa-siswi itu sendiri.

Sebagaimana hasil wawancara dengan wakil kepala sekolah bidang kesiswaan SMPN 2 jember yang mengatakan bahwa kegiatan ekstrakulikuler merupakan kegiatan yang terkoordinasi terarah dan terpadu dengan kegiatan lain di sekolah, guna menunjang pencapaian tujuan kurikulum. Dengan demikian, kegiatan ekstrakulikuler di sekolah ikut andil dalam menciptakan tingkat kecerdasan siswa. Kegiatan ini bukan termasuk materi pelajaran yang terpisah dari mata pelajaran lainnya, bahwa dapat dilaksanakan disela-sela penyampaian materi pelajaran, mengingat kegiatan tersebut merupakan bagian penting dari kurikulum sekolah.

Bentuk-bentuk kegiatan ekstrakulikuler juga mempertimbangkan tingkat pemahaman dan kemampuan peserta didik serta tuntutantuntutan lokal di mana sekolah maupun lembaga berada. Sehingga melalui kegiatan ekstrakulikuler diharapkan peserta didik mampu belajar dan memecahkan masalah yang berkembang di lingkungan sekitar

\section{Membangun Pola Berbasisi Komonitas; Upaya Memperkuat Kontrol}

Desain berbasis komonitas dimana sekolah melibatkan orang tua dan masayarakat dalam membentuk akhlak peserta didik. SMN 2 Jember menggunakan pola kerjasama antara keluarga, masyarakat, dan sekolah (tripusat pendidikan) oleh karena itu peran ketiganya tidak bisa dipisahkan. Selain melibatkan lingkungan masyarakat dan orang tua sekolah juga melibatkan penguatan literasi siswa yang dalam hal ini pemahaman terhadap media informasi. Disadari bersama semua komponen kehidupan tidak terlepas dari media seperti hand phone atau smartphone yang bisa memberikan informasi apapun kepada siswa. Oleh 
karenanya control dari masyarakat dan kelurga dibutuhkan untuk bisa memfilter content yang bisa merusak pikiran siswa.

\section{Kesimpulan}

Desain Pendidikan Akhlak di SMP Negeri 2 Jember dengan menerapkan empat model, pertama terintegrasi dengan kegiatan belajar mengajar (KBM) dimana setiap Pendidik mata pelajaran mengintegrasikan kedalam RPP. Kedua buadaya sekolah yang merupakan aktifitas yang biasa disebut bidden curriculum yang meliputi kegiatan rutin yang merupakan kegiatan yang sudah terprogam, kegiatan spontan, suritauladan/ keteladanan dari tenaga pendidik dan tenaga kependidikan, pengkondisian fisik maupun non fisik. Ketiga kegiatan ekstra kurikuler yang merupakan kegiatan tambahan di SMPN 2 Jember, yang memberikan gambaran akan pentingnya nilai kemandirian dan bakat minat siswa. Keempat Kegiatan berbasis Komonitas yang melibatkan orang tua dan masyarakat dalam pelaksanaan pendidikan akhlak. Dimana fungsi dari komonitas ini sebagai control siswa dalam hal kegiatan yang berada diluar sekolah. 


\section{Daftar Pustaka}

Akhmad Muhaiin Azzet. 2011. Urgensi Pendidikan Karakter di Indonesia. Yogykarata: Ar-Ruz Media

Al Ghazali Imam. 1990. Ihya' Ulumiddin. Semarang: CV Asy Syifa.

Aqib, Zaenal. 2002. Profesionalisme Pendidik dalam Pembelajaran. Surabaya: Cendikia.

Arifin, Miftah. 2007. Pendidikan Akblak dalam Presfektf Imam Al-Ghazali. Jember: Center For Society Studies

Arikunto, Suharsimi. 2002. Prosedur Penelitian: Suatu Pendekatan Praktek . Jakarta: Rineka Cipta.

Asmani, Ma'mur Jamal. 2013. Buku Panduan Internalisasi Pendidikan Karakter di Sekolah. Jogjakarta: Diva Press

Asrohah, Hanun. "Pendidikan Akhlak: Problem dan Perspektif', Nizamia, Vol.5, No. 2 (Agustus 2012)

Azra, Azyumardi. 2002. Paradigma Baru Pendidikan Nasional: Rekontruksi dan Demokratisasi . Jakarta: Kompas.

Dakir, 2004. Perencanaan dan Pengembangan Kurikulum . Jakarta: PT Rineka Cipta.

Depdiknas, 2005. Undang Undang No.14 tabun 2005 Tentang Pendidik dan Dosen Jakarta: Depdiknas RI

Haikal Husain, 2012, Wanita Dalam Pembinaan Pendidikan Karakter Bangsa, Yogyakarta: Pustaka Pelajar.

Hamalik, Oemar. 1999. Kurikulum dan Pembelajaran . Jakarta: Bumi Aksara, Jakarta.

Iswanto, Agus. 2009. Pendidikan Agama Islam Dalam Presfektif Multikulturalisme. Jakarata: Balai Litbang Agama Jakarta

Khoe Yau Tung, 2002. Simphoni Pedih Pendidikan Nasional. Jakarta: Abdi Tandur Komar, Oong, 2006, Filsafat Pendidikan Nonformal, Bandung: CV Pustaka Setia,

Langgulung, Hasan. 2010. Beberapa Pemikiran tentang Pendidikan, Bandung: alMaarif.

Lickona Thomas, Pendidikan karakter Panduan Lengkap Mendidik Sisiwa Menjadi Pintar dan Baik, Yogyakarta: Nusa Media, 2013

Machali Imam. 2011. Pendidikan Karakter Pengalaman Pendidikan Karakter di Sekolah. Yogyakarta: UIN SUKA Press

Majelis Luhur Persatuan Taman Siswa, 1977. Karya Ki Hajar Dewantara Bagian I Pendidikan . Yogyakarta: MLTM.

Masduqi, 1991. Leadership, Teori Kepemimpnan Sebuah Tatapan Perkembangan Zaman, Pasuruan: GBI.

Megawangi, Ratna. 2004. Pendidikan Karakter Solosi yang Tepat Untuk. Membangun Bangsa. Jakarta: Indonesia Heritage Foundation.

Foundation. 
120 | TADBIR : Jurnal Studi Manajemen Pendidikan, Vol. 2, No. 2, Desember 2018

Miskawaih, Ibn. 1934. Tahzib al-Akblak . Beirut: Dar al-Kutub al-Arabi.

Muhadjir, Noeng. 2004. Metodologi Penelitian Kualitatif. Yogyakarta: Rake Sarasin.

Muhajir, 2011, Pendidikan Karakter "Pengalaman Pendidikan Karakter di Sekolab", Yogyakarta: UIN Press

Taufiqurrahman, Pembentukan Karakter mahasiswa dalam system pendidikan Tinggi Islam, E- Journal Tadris Jurnal Pendidikan Islam Vol 13, No 1 (2018), IAIN Madura 